\title{
The Effect of Head of Local Government Characteristics and Internal Control System on Corruption Level in Indonesia
}

\author{
A Fontanella ${ }^{1}$, A W Ahmad ${ }^{2}$, S Sukartini ${ }^{3}$, N Chandra ${ }^{4}$ \\ Department of Accounting, Politeknik Negeri Padang, Indonesia ${ }^{1,2,4}$ \\ Kampus UNAND Limau Manih, Padang, Indonesia ${ }^{3}$ \\ $\left\{\right.$ amyfontanella99@gmail.com ${ }^{1}$, afridianpadang@gmail.com² ${ }^{2}$ tiensukartini28@gmail.com ${ }^{3}$, \\ novrina.chandra@gmail.com ${ }^{4}$ \}
}

\begin{abstract}
This research investigates the effect of head of local government characteristics (age, education level, and experience) on corruption level in Indonesia. It also tests the influence of internal control system on relationship between head of local government and corruption. The study was conducted towards 84 heads of local government (regents/mayors) in Indonesia during 20102016. The study finds that older heads of local government tend to have higher corruption level. Education level and experience, both from bureaucratic or nonbureaucratic and incumbent or non-incumbent have no significant effect towards corruption. The partial role of internal control has proven to restrain head of local government to commit corruption, particularly of the heads of local government who are aged and those with bureaucratic experience. This study also involves local own-source revenue (Pendapatan Asli Daerah/PAD), society characteristics, financial report accountability, and local government performance as the control variables
\end{abstract}

Keywords: Corruption, Characteristics, Local Government, Internal Control. 


\section{Introduction}

Corruption and power are highly correlated. Lord Acton, a professor at University of Cambridge, UK, was the one who stated that "power tends to corrupt and absolute power corrupts absolutely". This statement shows that corruption and power have simultaneous relationship in which corruption often follows the journey to obtain power, and vice versa, power is commonly used as an 'entrace' to corruption [1]. Hierarchical organizational structure, conflict of interest, and asymmetric information trigger a leader with power and vital role in giving influence on organizational outcome in various level to use this situation for his personal interest [2].

Corruption has become endemic infectious virus and problem in many countries, and spoiled cultural, political, and economic arrangement of the society [3]. In the public sector organizations, corruption is an agency cost that raised from asymmetric information [4]. A leader who has more information would opportunistically use his power to optimize his selfinterest. Such oppportunistic behaviour of the leader, or in this case, agent (manager) would turn to cost that would be beared by public as the ultimate owner of a country.

For Indonesia, phenomenon of corruption is nothing new. The failure of Verenigde Oost Indische Compagnie(VOC) in this country more than a century ago has become a real evidence of the impact of financial misappropriation and mismanagement (Halim and Abdullah, 2006). This then continued and got even worse when there was local autonomy requiring power decentralization to the local region [5]. Local autonomy is regulated in Law Number 32 Year 2004 aboutLocal Government and Law Number 33 Year 2004 about Balance Funding between Central Government and Local Government which are initiated to establish decentralized development. Unfortunately, authority decentralization is also followed by corruption decentralization [5], in accordance with prior statement from Acton.

Corruption has geographically and individually broaden in every government level. After the implementation of local autonomy, corruption starts to enter local government bodies in all managerial level of local government (top, middle, lower)[5]. Numerous institutions which conduct observation and survey show supporting data that the corruption trend is indeed widened and increased. Transparency International data shows that Indonesia is at 144 out of 177 countries in Corruption Perceptions Index (CPI) in 2013 having 32 as the score. Ministry of Internal Affairs also records that there are 291 heads of local government - governors, regents, and mayors, involved in corruption caseswithin the period of 2004-2013. Indonesia Corruption Watch (ICW) released that during 2012, there were 44 political party cadres who were involved in corruption, having 21 members/ex-members of House of Representatives/House of Local Representatives, 21 heads of local government and two board members of political party.

There are numbers of research which have investigated determinant, impact, and cause of corruption [6]-[10]. Education, experience, and gender are amongst internal individual factors which have effect on corruption [6], [8], [11]. Other researchers studied external individual factors, e.g., media role, economic and social heterogeneity, regulation, fiscal decentralization, public belief level, internal control, law enforcement, and political and economic stability [9], [10], [12].

Out of those factors, management characteristics is the main one which influences corruption. A head or leader with high education level would have less possibility to commit corruption as the higher academic and intellectual skill a person has, the better virtues and kindness the person would own [6]. Besides, education would also enable an individual to acquire better awareness of social responsibility so that the person would not expropriate rights of others [7]. Alongside with the education factor, literatures have also found negative relationship between age and 
corruption level [11]. The theoriesbelieve that that the older someone is, the wiser that person would become, but on the other hand, the study also finds that younger head or leader would typically has high idealism which would lessen the tendency for doing corruption [13]. Experience of a leader has also been proven to have effect on corruption level, yet the results still varied as some find it negative [1] while some other find it positive[8].

It is important to investigate the effect of management characteristics (head of local government) on corruption and the role of internal control system on government of Indonesia as for some reasons. First, ICW data in 2010 shows that local finance is at the second place of the biggest corruption in Indonesia causing the country to suffer from IDR 417,4 billionloss. The data also presents that regency and city are the main corrupt institutions which instigate the biggest loss for the state. Second, concerning the regulation of financial management Government Regulation Number 58/2005 which states that head of local government is the one who holds authority for local finance management and represents local government in owning the separated own-source. This law explicates about the broad authority owned by a head of local government so that the chance to do moral hazard and opportunistic behavior with such power would be wide open. This is supported by data showing corrupt heads of local government (291) during the period of 2004-2013 (ICW, 2014).

Based on that phenomenon, this study would investigate the effect of head of local government characteristics on corruption. Moreover, it would also test the moderation role of internal control system in giving influence to the relationship of head of local government characteristics and corruption level. This research has three main purposes, i.e., to investigate and analyze the influence of head of local government characteristics towards corruption level, to examine and evaluate the influence of internal control system effectiveness in local government towards corruption level, and to find out about the effectiveness of internal control system in local government to moderate the characteristics of head of local government towards corruption level.

This study is expected to give several contributions. The first is through literature enrichment by providing empirical evidence which specifically investigates the effect of internal control system moderation on the relationship of head of local government characteristicsand corruption level. Research studies with particular topic on corruption and accounting are still considered rare. This journal is presented to fill that existing gap by involving internal control system as corruption determinant. The second is by comprehensively analyzing corruption determinant by putting several control variables, e.g., financial report quality, local government performance, region own-source revenue, and society characteristics

\section{Literature Review And Development Of Hypotheses}

\section{I Agency Theory in Public Sector Organization Context}

Agency theory describes about the relationship of principal with owner and it is used as a basic concept in corporate business practice. Even so, this theory is still very relevant once employed in public sector organization context. Moe [14] also finds that economic concept in public sector organization could be explained using the agency theory. Bergman \& Lane [15] state that agent-principal-relationshipframework is a crucial approach to analyze public policy commitment. The formulation and implementation of public policy relates to contractual matters; asymmetric information, moral hazard, and adverse selection. 
In agency model, there are two motivations of agent behavior monitoring [16], namely behavior-based (where principal must monitor the agent's behavior) and outcome-based (where there are incentives to motivate agent to meet the principal's interest). According to Moe [14], there is relationship of principal-agent agreements that are able to be traced through budgeting process: voters-legislators, legislators-government, ministerof finance-budget users, prime minister-bureaucrat, and officers-service providers.

\subsection{Corruption}

Different writings have portrayed a number of definitions about corruption. Robinson [17] defines corruption as aviolation of role or public resources for personal interest. Transparency Indonesia explains that corruption is power misuse for personal interest. Johnston in Hoon (2003) gives typology of corruption definition by classifying it into two aspects: corrupt behavior and principal-agent relationship. Aspect of behavior interprets corruptionasmisuse of power, authority, and public bureau (government)for personal interest. Zimelis [18] explicates that corruption is an abuse towards law norm of the society or breakage of rules in order to obtain personal benefit. This study would utilize the definition of corruption published by Transparency International and World Bank: "Corruption is misuse of public power for private gain.

Research studies that have explored factors which influence corruption in a country mostly focus on economic, law, political, and cultural aspect. Zimelis [18] finds that the main factor which influences corruption is income. Countries with high income per capita would have low corruption level, and vice versa. Some other works focus on human capital aspect as a factor influencing corruption level. Education, experience, gender, and leadership factor are found related to corruption level [6], [11]. Other researcherssee more macroeconomic factors, for instance, law enforcement, political stability, fiscal decentralization, and public belief in corruption [7], [9], [10]. Nevertheless, this result is still inconclusive. Cheng and Chan find that education level negatively relates to corruption while other studies find it the other way around. Such inconsistency is also found regarding aspect of age and work experience as some studies discover negative relationship while others turn out to have thecontrary results, and even there are writings which find no relationship between these two. These differences and inconsistencies are strongly affected by context and area of the research.

\subsection{Prior Research Review and Hypotheses Development}

\section{Leader Characteristics and Corruption}

Leader characteristics in this research is viewed from three points: education level, work experience, and age. Several previous research studies about the effect of education level on corruption have demonstrated different results. Treisman [19] finds negative relationship between education level and corruption. This negative relationship is based on the perspective that individual with higher education level would have better values and belief in kindness and virtues compare to other individuals [8].

Apart from that, higher education level would give more space to virtues and social responsibility so that an individual having high education level would have lower tendency to do corruption [3]. However, other studies are unable to prove the effect of education level on corruption [10]. A leader with high education level would have the capability to manage organization in a more effective and efficient way since the person has proper knowledge to. 
Such leader would as well be more responsible to the environment, society, and other parties who grant the chance to become a leader.

\section{H1: Education level of head of local government has negative effect on corruption level}

Age is also a factor which has been investigated to see whether it has influence on corruption level or not. Long (1992) finds negative relationship between age and corruption level. More senior individual would have more life experience. This would enable the person to be wiser with no interest to take other's rights away. In addition, as people get older, they would be more obedient and observing towards religious values and they would not tend to violate the religious teachings [11].

In spite of that, other studies find contradictory results. These writings show that there is positive relationship of age and corruption level. It is based on a view that younger leader has better dedication, commitment, and idealism. A leader who achieves such position at a young age is typically smart, having a lot of organizational experience and outstanding managerial skill. Hence, the heads of local government who are still young, especially those who are elected by the public, would commonly have good characteristics.

H2: Age of head of local government has negative effect on corruption level.

The subsequent factor regarding characteristics is work experience. With regard to corruption, there would be two sides which are relatively different. On one hand, corruption is found negatively related to experience [1]. An individual with more experience would manage the organization better. If the person understands the business process of the organization well, then he would make better decision. Also, a more experienced individual, with good track record, would gain better trust from the society. The more experienced the person is, the easier people would evaluate his performance.

Both public trust and experience would make the individual more reliable, therefore he would not do any fraud or harm the rights of others. On the other hand, an experienced person who has been in the same position for some period of time would have extraordinary understanding about condition in the organization. Once this happens, the individual, particularly the one having great authority, would be able to identify every niche of the organization's weakness which then could be used opportunistically [8].

H3: Experience of head of local government has negative effect on corruption level.

\section{Internal Control System and Corruption}

Internal control is designed to have accurate and reliable data, protect assets of the company, and enhance effectiveness of members of the company in order to function accordingly to its objectives. Coram et al. describes that organization which has internal audit function could detect accounting fraud better. Study of Hogan et al. (2008) discusses about the role of auditor in reducing accounting fraud. Bastian [20] says that the accounting control is a part of internal control system which covers coordinated organizational structure, methods, and measurements, mainly to preserve assets of the organization and ensure thoroughness and reliability of the accounting data. Aggrey (2012) finds that internal control system could lower corruption level. This indicates that internal control system restrains opportunistic behavior of manager through proper monitoring mechanism and this is similarly discovered by Liu and Lin (2012). 
H4: Internal control system has negative effect on corruption level.

Other than direct impact of internal control system towards corruption, this study would also address the moderation roleof internal control system. If the internal control mechanism is proper, then it would have the ability to restrain opportunistic behavior and weaken management characteristics for corruption.

H5: Internal control system would strengthen negative effect of management characteristics on corruption level.

\section{Research Method}

This research is conducted in regency and city governments in Indonesia which are listed as Corruption Perceptions Index (CPI) objects in the year of 2010-2016. This study uses a collection of secondary data of CPI published by Transparency International, head of local government biography data, Ministry of Internal Affair performance data, investigation report data of Audit Board of Indonesia and human development index. For this research, the samples without complete data are taken out and the total amount of final samples are 84 heads of local government. To test $\mathrm{H} 1-\mathrm{H} 4$, the following model is used:

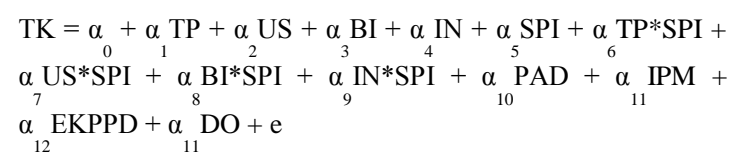

Note: $\mathrm{TK}=$ corruption level, $\mathrm{TP}=$ education level, $\mathrm{US}=$ age, $\mathrm{BI}=$ experience $($ Bureaucratic vs non- bureaucratic), IN = experience (incumbent vs non-incumbent), SPI = Internal Control System, PAD = region own-source revenue, IPM = human development index, EKPPD = Local Government Management Performance Evaluation, DO = audit opinion

The dependent variable is Corruption Perceptions Index (CPI) released by TI. CPI range in Indonesia is $0-10$ where 0 means highly corrupt and 10 indicates very clean condition. That is why, the study multiplies CPI score by minus $1(-1)$ to see the corruption level in those areas. Meanwhile, the independent variables are education level, age, experience (bureaucratic vs nonbureaucratic and incumbent vs non-incumbent), and internal control system. Independent variables operationalization could be seen below.

Education Level $\quad$ : Study duration (high school: 12 years, bachelor: 16 years,

Age

Experience (bureaucratic :

vs non-bureaucratic)

Experience (incumbent vs : non-incumbent)

SPI

\section{master: 18 years, doctoral: 21 years}

Age of the head of local government

1 if the background is bureaucratic, 0 if not

1 if the background is incumbent, 0 if not

: Findings of internal control system of the local government based on investigation report of Audit Board of Indonesia 
This research uses some control variables: region own-source revenue, society characteristics (Human Development Index), local government performance, and quality of local government financial reports (audit opinion).

\section{Data Analysis And Discussion}

This study is about regent/mayor and representatives in Indonesia. From the education level, majority of head of local government has master degree, which is $68 \%$, while $24 \%$ has bachelor degree and $9 \%$ of them has doctoral degree. Based on this fact, it could be concluded that on average, educational qualification and characteristics of the heads of the local government are on satisfactory level.

From the age point of view, most are in the range of 41-50 years (38\%) and 51-60 years $(38 \%)$. Only a few numbers of them who are $30-40$ years, counted as $6 \%$. Based on the age distribution, they are in the productive age range (15-64 years). Seen from the background experience aspect, the comparison between those who have bureaucratic background and nonbureaucratic ones are rather balance (44\% and 56\%). By the same token, their tenure comparison has quite similar fact with $53 \%$ incumbent samples, having the rest as non-incumbent.

This study uses two perspectives to analyze the 4 hypotheses, which are about the effect of management characteristics on corruption level and the moderation role of internal control system on the relationship between management characteristicsand corruption level. Overall, the regression shows that $59 \%$ dependent variable variation could be explained by the independent variables (adjusted $\mathrm{r}$ square $=59.9 \%$ ). The table also demonstrates that the probability of $\mathrm{F}$ statistic is smaller than alpha, which means that there is no problem withthe model and that it is usable.

Table 1. Hypotheses Test

\begin{tabular}{lrrrr}
\hline Dependent Variable: IPK & & & & \\
\hline Variable & Coefficient & Std. Error & \multicolumn{1}{c}{ t-Statistic } & \multicolumn{1}{l}{ Prob. } \\
\hline C & 4.010055 & 1.900613 & 2.109875 & 0.0412 \\
\hline USIA & -0.02269 & 0.010625 & -2.135719 & 0.0026 \\
\hline TP & -0.04725 & 0.082426 & -0.573291 & 0.5697 \\
\hline DS & 0.144355 & 0.156962 & 0.919679 & 0.3633 \\
\hline DLP & 0.17083 & 0.182197 & 0.937615 & 0.3541 \\
\hline SPI & -0.24246 & 1.87856 & -0.129066 & 0.898 \\
\hline USIA*SPI & 0.041683 & 0.014823 & 2.812035 & 0.0021 \\
\hline TP*SPI & 0.054514 & 0.101081 & 0.539313 & 0.5927 \\
\hline DLP*SPI & 0.565272 & 0.281125 & 2.010745 & 0.0476 \\
\hline PAD & $-1.11 E-06$ & $1.04 \mathrm{E}-06$ & -1.073227 & 0.2896 \\
\hline IPM & 0.008093 & 0.02239 & 0.361457 & 0.7197 \\
\hline IPK08 & 0.026741 & 0.092987 & 0.287577 & 0.7752 \\
\hline EPPD & 0.038686 & 0.150496 & 0.257058 & 0.7985 \\
\hline DO & 0.383146 & 0.16463 & 2.327323 & 0.0025 \\
\hline Adjusted R-squared & 0.59926 & S.D. dependent var & 0.704535 \\
\hline F-statistic & 7.096556 & Durbin-Watson stat & 1.143092 \\
\hline & & & & \\
\hline
\end{tabular}




\begin{tabular}{l}
\hline Prob(F-statistic) 0.000001 \\
\hline IPK = Corruption Perceptions Index (0: highly corrupt, 10: very clean), Usia = age of the \\
head of local government, TP = education level (high school, bachelor, master, doctoral \\
degree), DLP = work background (1: bureaucratic, $0:$ non-bureaucratic), DS = status (1: \\
incumbent, $0:$ non-incumbent), SPI = internal control system findings, PAD = region own- \\
source revenue, IPM = human development index, EPPD = local government management \\
evaluation, DO = audit opinion (3: unqualified, 2: qualified, 3: disclaimer ) \\
\hline
\end{tabular}

\subsection{Management Characteristics and Corruption}

Management characteristics aspect is investigated from three factors; education, age, and experience of head of local government. Concerning the first hypothesis, there is no significant effect of education level on corruption found. It means that education level of head of local government does not affect the possibility to commit corruption ( $\mathrm{H} 1$ is rejected). The belief that high education would enhance better virtues and honesty [13] is not proven. The conclusion of Long (1992): high education would provoke better awareness about social responsibility iseither not confirmed in this study.

The second hypothesis about age states that the older someone is, the more life experience he would have. Thus, the person would have better wisdom and lower tendency to do corruption. Interestingly, this study reveals a conflicting result. This means that the corruption level would raise once the head of local government is older. This is consistent with Cheng and Chan (2012) who conclude that young leaders have higher idealism so that they have lesser drive to commit corruption.

Regarding the work experience, it is measured by 2 proxies: whether the head of local government has earlier experience as bureaucrat, and whether he is an incumbent. The head of local government who has bureaucratic background having the incumbent position on the prior period has more experience and slighter possibility to do corruption. Yet this hypothesis 3 is not verified. This study finds that experience, both as incumbent and bereaucrat have no significant effect on corruption level. The view which says that experienced leader would manage the organization better and more honestly [1] is then not proven.

\subsection{Moderation Role of Internal Control System in Affecting the Relationship between Characteristics and Corruption}

Internal control system has no direct influence on corruption level. However, according to statistic, interaction between age and internal control system is significantly positive. This means that internal control system could restrain opportunistic behavior of older heads of local government. This fact is in line with Liu and Lin (2012) who find that good internal control system would enhance transparency and reduce corruption. Interaction between experience of head of local government as bureaucrat and internal control system is significant. This is consistent with the view which states that internal control would strengthen negative relationship between head of local government having bureaucratic background with corruption level.Head of local government who has experience as bureaucrat has acquires great understanding of the government condition and effective internal control system would restrain him to commit corruption. The only significant control variable in this study is audit opinion 
which is a proxy of local government financial reports. Local government with accountable financial reports tend to have less corruption compare to others with unaccountable ones.

\subsection{Discussion and Analysis}

This research investigates the influence of characteristics of the head of local government towards corruption and moderation role of internal control system. The regression result shows that age is the only factor with positive influence towards corruption while education level and experience, both as bureaucrat and incumbent,areinsignificant. This indicates that corruption is more likely influenced by internal factor and individual morality which are abstract and relatively hard to measure [9]. Education level and work experience would have no effect on corruption level as long as the authorized individual has no internal values that would restrain himself to do moral hazard. Corruption happens when there is ability and / or opportunity to. Besides, this research does not usecontrol of external factors, such as law enforcement, and economic and political stability which would influence corruption level as found by Hoon (2003). Having these factors uncontrolled could become the alternative response. The sample size of this research, which are rather small, could also affect the result.

Regarding age factor, there is positive relationship between age and corruption level. This finding demonstrates that older person has bigger possibility to commit corruption. This is in line with the theory which believes that young leaders have more idealism which personally would restrain them from doing corruption [13]. For Indonesia, this finding is relevantto some extent. The role of young heads of local government in the country has now become public attention in the course of their breakthrough and movement to shift old paradigm to a more transparent and creative leadership pattern. Furthermore, individuals who have become leaders at young age are usually those with outstanding skills, good managerial level, and with high idealism [9]. These internal values would limit them from committing opportunistic action.

Internal control system is aimed at ensuring reliability of accounting information, compliance with regulation, and advancement of effectiveness and efficiency of the organization [3]. Good internal control system would overcome asymmetric information between agent and principal, plusrestrain agent from doing opportunistic action, for example, misuse of public authority for self interest (corruption). Internal control system could moderate the influence of management characteristics on corruption. The finding of this research has partially confirmed hypothesis about the moderation role of internal control, particularly related to age and experience as bureaucrat. Internal control system is proven to be able to controlthe head of local government from doing corruption, especially if he has prior experience as bureaucrat. Such experienced head of local government would have great understanding about the organization condition, including the internal control system, so that the person would not prefer to take risky action, like committing corruption.

\section{CONCLUSION AND SUGGESTIONS}

This research investigates the effect on head of local government characteristics on corruption. Moreover, it also empirically tests the moderation role of internal control system in affecting the relationship between characteristics and corruption level. As a dependent variable, corruption level is measured using CPI ofTransparency International. Independent variables in this research are education level, age, work experience (bureaucratic / non-bureaucratic and incumbent / non-incumbent). The result shows that age is the only variable which has positive influence towards corruption while others are insignificant. This study also tests the impact of 
moderation role of internal control system towards the relationship of characteristics and corruption. Partially, internal control system is proven to have the ability to restrain the head of local government from committing corruption, particularly if the person is quite aged, with previous experience as bureaucrat. This research includes several control variables; local ownsource, society characteristics (human development index), quality of financial reports (audit opinion of Audit Board of Indonesia), Corruption Perceptions Index of the preceding year, and local government performance.

This study has certain limitations. First, it is only conducted in 84 local areas so due to thislimited sample size, it isthen not able to be generalized for other areas. Second, the use of Corruption Perceptions Index (CPI), as a proxy for corruption has certain weaknesses, i.e., it is perceptive and its small survey scope has no ability to capture the whole perceptionof stakeholders. Third, this study omits external control variables, such as law enforcement, and economic and political stability into the research model and this could lead to wrong conclusion.

The next research is advised to cover more samples using other proxies to measure corruption level. Development could also be done by adding marcoeconomic control variables, for instance, law enforcement, and economic and political stability to obtain more comprehensive understanding.

\section{References}

[1] S. Bendahan, C. Zehnder, F. P. Pralong, and J. Antonakis, "Leader corruption depends on power and testosterone," Leadersh. Q., vol. 26, no. 2, pp. 101-122, 2015.

[2] D. F. Flynn, N. Mirotchnick, M. Jain, M. I. Palmer, and S. Naeem, "Functional and phylogenetic diversity as predictors of biodiversity-ecosystem-function relationships," Ecology, vol. 92, no. 8, pp. 1573-1581, 2011.

[3] A. Zimelis, "(NON) DETERMINANTS OF CORRUPTION: A SCEPTICAL VIEW FROM EASTERN EUROPE.," J. Comp. Polit., vol. 4, no. 2, 2011.

[4] A. Syukriy and A. Halim, "Studi atas Belanja Modal padaAnggaran Pemerintah Daerah dalam Hubungannya dengan Belanja Pemerintahan dan Sumber Pendapatan," J. Akunt. Pemerintah, vol. 2, no. 2, 2006.

[5] I. C. Watch, "Public Review terhadap Rancangan Revisi Permentan 26/2007 Tentang Pedoman Izin Usaha Perkebunan," 2013.

[6] B. Dong and B. Torgler, "Causes of corruption: Evidence from China," China Econ. Rev., vol. 26, pp. 152-169, 2013.

[7] N. Aggrey, "Determinants of corruption at district levels in Uganda," J. Econ. Manag. Perspect., vol. 6, no. 4, p. 67, 2012.

[8] D. Treisman, "What have we learned about the causes of corruption from ten years of cross-national empirical research?," Annu. Rev. Polit. Sci., vol. 10, pp. 211-244, 2007.

[9] L. Balafoutas, "Public beliefs and corruption in a repeated psychological game," J. Econ. Behav. Organ., vol. 78, no. 1-2, pp. 51-59, 2011.

[10] H. Park, "Determinants of corruption: A cross-national analysis," Multinatl. Bus. Rev., vol. 11 , no. 2 , pp. 29-48, 2003.

[11] A. Swamy, S. Knack, Y. Lee, and O. Azfar, "Gender and corruption," J. Dev. Econ., vol. 64, no. 1, pp. 25-55, 2001.

[12] J. Liu and B. Lin, "Government auditing and corruption control: Evidence from China's provincial panel data," China J. Account. Res., vol. 5, no. 2, pp. 163-186, 2012.

[13] H. Y. Cheung and A. W. H. Chan, "Corruption across countries: Impacts from education and cultural dimensions," Soc. Sci. J., vol. 45, no. 2, pp. 223-239, 2008. 
[14] T. M. Moe, "The new economics of organization," Am. J. Pol. Sci., vol. 28, no. 4, pp. 739-777, 1984.

[15] M. Bergman and J. E. Lane, "Public policy in a principal-agent framework," J. Theor. Polit., vol. 2, no. 3, pp. 339-352, 1990.

[16] J. B. Carr and R. S. Brower, "Principled opportunism: Evidence from the organizational middle," Public Adm. Q., vol. 24, no. 1, pp. 109-138, 2000.

[17] B. E. Robinson, "The workaholic family: A clinical perspective," Am. J. Fam. Ther., vol. 26, no. 1, pp. 65-75, 1998.

[18] A. Zimelis, A. Lazdinšs, and A. Sarmulis, "Comparison of productivity of CBI and MRC-500 stump lifting buckets in Latvia,” Res. Rural Dev., pp. 59-65, 2013.

[19] D. Treisman, "The causes of corruption: a cross-national study," J. Public Econ., vol. 76, no. 3, pp. 399-457, 2000.

[20] I. Bastian, Akuntansi sektor publik: suatu pengantar. Jakarta: Erlangga, 2006. 